Вадим Рижиков, доктор педагогічних наук, професор Військовий інститут Київського національного університету імені Тараса Шевченка, м. Київ ORCID ID 0000-0001-7069-7040

Олег Прохоров, кандидат педагогічних наук, доцент Військовий інститут Київського національного університету імені Тараса Шевченка, м. Київ ORCID ID 0000-0002-3246-8850

Олег Колісник, кандидат психологічних наук, доцент Національний університет оборони України імені Івана Черняховського, м. Київ

ORCID ID 0000-0002-6208-9106

DOI: $10.33099 / 2617-1775 / 2020-02 / 270-281$

\title{
СУЧАСНИЙ СТАН, ЦІЛІ ТА ЗМІСТ, ПРОБЛЕМИ І ПЕРСПЕКТИВИ РОЗВИТКУ ВІЙСЬКОВОЇ ОСВІТИ В УКРАЇНІ
}

В статті висвітлюються особливості підготовки військовослужбовиів в сучасних умовах участі України у гібридній війні, аналіз сучасного стану, иілей та змісту, проблем $i$ перспектив розвитку військової освіти. Військова освіта базується на принципах науковості, гуманізму, демократизму, послідовності та безперервності, незалежності від втручання будь-яких політичних партій, рухів, інших громадських та релігійних організацій $i$ здійснюється на засадах компетентнісного підходу.

В науковій статті практичною складовою є запровадження інтерактивних форм навчання, а саме ділових та рольових ігор в освітньому прочесі військового навчального закладу, які максимально наближають теоретичну підготовку до реальної практичної діяльності, тому що ділові та рольові ігри є основою прийняття рішень як в конкретній бойовій обстановиі, так і на заняттях, сприяють формуванню знань, законів, тендениій розвитку військової справи, логічних методів системного аналізу. Велике значення для організаиії рольової гри мають прийоми, які засновані на стимулюванні ігрових взаємодій курсантів в максимальній наближеності до реальної професійної військової бойової діяльності офіцера - поведінково-ігрові прийоми. До числа таких прийомів належать: інструктування, активізація ігрових сторін, корекція поведінки учасників гри, прийоми етапної та підсумкової очінок. Особливе значення в процесі організації рольових ігор в професійній підготовиі військових мають так звані когнітивно-ігрові прийоми. До таких прийомів відносяться: а) прийоми, які сприяють входженню в роль - образ (характеристика ролі кожного учасника гри, спонукання, заохочення, питання-підказка, а також підбадьорення $i$ гумор); б) прийоми кореляиії ролей (постановка навідних питань, зауваження-питання, підтримка-захист та інше).

Сьогоднішній період характеризується серйозними структурними й організаційними змінами у сфері державотворення та військового будівництва, у тому числі щодо системи вищої військової освіти (СВВО). Характерною відмінною ознакою функціонування СВВО на сучасному етапі $\epsilon$ те, щзо вона виступає водночас й інструментом, й об'єктом реформування Збройних Сил Украӥни, оскільки від професійної підготовки офіцерських кадрів, їх відданості Вітчизні і спроможності виконувати військовий обов'язок у найвищому ступені залежить боєготовність та боєздатність військ. Тому СВВО повинна забезпечити 
підготовку військових фахівців із високим рівнем професіоналізму, компетентності, інтелектуального розвитку, загальної та військово-професіональної культури, здатних $з$ високою ефективністю виконувати поставлені завдання щодо оборони України, розвитку власної творчої індивідуальності, наполегливого самостійного засвоєння нових знань протягом військової служби, прийняття оптимальних рімень в нестандартних умовах за всіма спеціальностями й спецііалізаціями, щзо визначають рівень боєздатності та боєготовності Збройних Сил.

Ключові слова: військова освіта; рольові та ділові ігри; освітній процес військового навчального закладу; система освітнього прочесу.

Постановка проблеми. Система військової освіти в Україні складається iз початкової військової підготовки, професійної військової підготовки молоді, вищої освіти військових фахівців та післядипломної освіти, яка включає в себе підвищення кваліфікації та перепідготовку офіцерських кадрів. Випускники вищих військових навчальних закладів (далі ВВНЗ) отримують ті ж освітньокваліфікаційні рівні, що i випускники цивільних закладів вищої освіти молодший спеціаліст, бакалавр, магістр.

Сучасний стан, цілі та зміст, проблеми і перспективи розвитку військової освіти в Україні наведено в наступних нормативно-правових документах, а саме: Конституція України [2], Указ Президента України «Про рішення Ради національної безпеки i оборони України від 20 травня 2016 року «Про Стратегічний оборонний бюлетень України» [13], Воєнна доктрина України, затверджена Указом Президента України від 24 вересня 2015 року № 555/2015, Концепція розвитку сектору безпеки і оборони України, затверджена Указом Президента України від 14 березня 2016 року № 92/2016, Стратегічний оборонний бюлетень України, уведений в дію Указом Президента України від 06 червня 2016 року № 240/2016 та інші нормативно-правові акти України визначають безпосередні завдання реформування військової освіти в контексті загальної реформи Збройних Сил України. Указ Президента України «Про Стратегічний оборонний бюлетень України» [13] передбачає запровадження на практиці у ВВНЗ НВП(ЗВО) передових методик підготовки збройних сил держав - країн членів НАТО, використання технологій дистанційного навчання, приведення змісту освіти та якості підготовки (перепідготовки) i підвищення кваліфікації військових фахівців у відповідність до потреб сил оборони та з урахуванням досвіду антитерористичної операції. Актуальність зазначених у вище названих нормативно-правових актах питань, становлять основу реформування військової освіти при запровадженні на базі кожного ВВН3 НВП(ЗВО) розроблених відповідних програм на основі зарубіжних методик підготовки військовослужбовців, технологій дистанційного навчання, оновлення змісту освіти, що надають освітньому процесу ВВНЗ НВП(ЗВО) у забезпеченні реформ військової освіти більшої практичної конкретизації.

Можливості успішної реалізації наведених напрямів значною мірою визначаються тепер і цей фактор буде зростати в майбутньому. Насамперед, рівнем освіченості й культури суспільства. Недарма стверджував Аристотель, що краще виховання забезпечує і кращий тип політичного устрою. Вже зараз на порозі третього тисячоліття повною мірою проявляється жорстка залежність 
нашої цивілізації від тих особливостей та якостей, що закладаються в освіті.

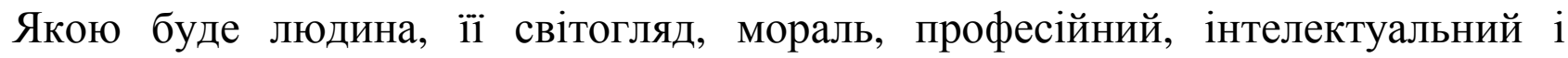
культурний рівень, іiі громадянська позиція багато у чому визначаються освітніми закладами а від їхньої діяльності без перебільшення можна сказати залежить майбутнє людства. Все зазначене стосується і військової освіти невід'ємної складової загальнодержавної освітньої системи. Створення системи військової освіти, іiі пріоритетний розвиток у будівництві та реформуванні Збройних Сил України стали важливою і відповідальною задачею Української держави.

Аналіз останніх досліджень і публікацій з проблеми, що розглядається у статті та означення аспектів загальної проблеми, яким присвячується стаття. Проблеми сучасного стану, цілі та зміст, проблеми і перспективи розвитку військової освіти в Україні є предметом уваги науковців в галузі педагогічної науки, а також керівництва держави, політиків, командування Збройних Сил України, зокрема, І.Руснака, О.Діденка, Г.Ложкіна, В.Маслова, М.Нещадима, Б.Олексієнка, В.Рижикова, В.Телелима, В.Ягупова та ін. Правовою основою реформ у галузі військової освіти є передусім Конституція України [2], Закон України «Про вищу освіту» [6], Положення «Про особливості організації освітньої діяльності у вищих військових навчальних закладах Міністерства оборони України та військових навчальних підрозділах закладів вищої освіти» Наказ Міністерства оборони України від 09 січня 2020 року № 4 [4].

Проблемам якості підготовки військових фахівців приділяли уваги в своїх працях С.Бурий, А.Зельницький, А.Кучерявий, О.Прохоров, І.Толок та ін.

Метою статті $\epsilon$ висвітлення особливостей підготовки військовослужбовців в сучасних умовах ведення гібридної війни, аналізу сучасного стану, цілі та змісту, проблем і перспектив розвитку військової освіти в Україні.

Методи дослідження. У статті використано окремі загальнонаукові та спеціальні методи теоретико-емпіричного дослідження, зокрема аналіз наукової літератури із проблеми, систематизація та узагальнення матеріалів.

Виклад основного матеріалу. Система підготовки військових фахівців, що створена в Україні, є складником державної системи освіти. У системі військової освіти знаходиться 12 ВВНЗ та ВПН ЗВО (2 університети, 4 академї, 6 військових інститутів); кафедри військової підготовки (5 - офіцерів кадру, 26 - офіцерів запасу). Три заклади мають статус «Національний» [14].

Військова освіта є складовою загальнодержавної системи освіти в Україні та включає понад 150 спеціалізацій і 70 спеціальностей. Підготовка військових фахівців здійснюється у галузі знань «Воєнні науки, національна безпека, безпека державного кордону» та у 21-й «цивільній» галузі знань за ліцензованими спеціальностями та спеціалізаціями. Це понад 70 спеціальностей та майже 150 спеціалізацій. Система військової освіти інтегрована у загальнодержавну систему освіти - випускники військових вузів після закінчення навчання отримують дипломи державного зразка освітніх ступенів «молодший спеціаліст», «бакалавр», «магістр». 
В освітній процес активно залучений офіцерський склад, який має бойовий досвід, запроваджено механізм ротації науково-педагогічних працівників. Значний відсоток офіцерів-викладачів військових навчальних закладів протягом останніх років брали участь у проведенні АТО та операції Об'єднаних сил на території Донецької та Луганської областей.

Освітній процес - це інтелектуальна, творча діяльність у сфері вищої та післядипломної військової освіти і науки, що провадиться у ВВНЗ ВНП ЗВО через систему науково-методичних, педагогічних заходів та спрямована на передачу, засвоєння, примноження і використання знань, умінь та набуття компетентностей особами, які навчаються, а також на формування гармонійно розвиненої особистості [4].

Військова освіта базується на принципах науковості, гуманізму, демократизму, послідовності та безперервності, незалежності від втручання будь-яких політичних партій, рухів, інших громадських та релігійних організацій і здійснюється на засадах компетентнісного підходу [4].

Підготовка офіцерів військового управління тактичного рівня здійснюється на базі повної загальної середньої освіти. Навчання може проводитися за різними схемами підготовки.

Перша схема. Підготовка офіцерів командного фаху. Вона здійснюється у ВВНЗ за напрямом "Військове управління" протягом 4 років за суто військовими спеціальностями. За цією схемою підготовки ті, хто навчаються, мають статус курсанта протягом всього терміну навчання.

Випускники отримують диплом про здобуття базової вищої освіти (освітньо-кваліфікаційного рівня бакалавра). Їм присвоюється кваліфікація “бакалавр - офіцер військового управління тактичного рівня”.

Навчання курсантів командного фаху у галузі знань "Військове управління" обумовлено неможливістю викладання необхідного обсягу навчальних дисциплін, що формують військового командира, на протязі 3,5-4 років в рамках навчання в інший цивільній галузі знань за відповідною бакалаврською програмою $[3 ; 4 ; 9 ; 12]$.

Друга схема. Підготовка офіцерів інженерного та гуманітарного (психологи, політологи, фінансисти тощо) фахів. Вона здійснюється у ВВНЗ та ВНП ЗВО України в цивільних напрямах підготовки ("Радіотехніка", "Інженерна механіка", "Психологія" тощо), як правило, за військовими спеціальностями. За цією схемою ті, хто навчаються, також мають статус курсанта протягом всього періоду навчання.

Курсанти після 4 років навчання проходять першу державну атестацію. Тим, хто успішно пройшов атестацію, присвоюється кваліфікація “бакалавр за фахом" та видається диплом державного зразка про здобуття базової вищої освіти за відповідною галуззю знань. Вони продовжують навчання у ВВНЗ, ВНП ЗВО за освітньо-професійними програмами підготовки магістрів протягом 1-1,5 років. По закінченню навчання передбачається друга державна атестація випускників. Тим, хто успішно пройшов атестацію, видається диплом державного зразка про здобуття повної вищої освіти (освітньо-кваліфікаційного 
рівня магістра) за відповідною галуззю знань та присвоюється кваліфікація “магістр за фахом, офіцер військового управління тактичного рівня".

Третя схема. Підготовка військових фахівців за спеціальностями, наближеними до цивільних. За такою схемою доцільно здійснювати підготовку військових фахівців з метеорології, правознавства, військової ветеринарії тощо. Підготовка проводиться у ВНП ЗВО на базі відповідних цивільних напрямів, як правило за цивільною спеціальністю 3 військовою спеціалізацією. За цією схемою ті, хто навчаються, мають статус студента протягом 4 років навчання (під час навчання за освітньо-кваліфікаційним рівнем бакалавра).

Після закінчення 4 курсу проводиться державна атестація, за результатами якої студенти отримують диплом цивільного бакалавра 3 військовим професійним спрямуванням. Перед початком 5-го року підготовки студенти складають Військову присягу i продовжують навчання в статусі курсанта. Протягом п’ятого року навчання курсанти опановують дисципліни магістерської програми підготовки у цивільній галузі знань. Випускники після державної атестації отримують диплом державного зразка про здобуття повної вищої освіти (освітньо-кваліфікаційного рівня магістра) за відповідною галуззю знань та їм присвоюється кваліфікація “магістр за фахом, офіцер військового управління тактичного рівня".

Випускникам ВВНЗ, ВНП ЗВО тактичного рівня встановлюється рівень військової освіти - вища військово-спеціальна освіта.

За роки незалежності в Україні створена єдина система військової освіти (далі $\mathrm{CCBO}$ ), яка являє собою соціальний інститут, що є складовою частиною державної системи освіти, покликаний забезпечити процес військової освіти та складається певною мірою з організованої сукупності освітніх закладів, які реалізують військову освіту згідно з чинними нормативноправовими основами, освітніми та освітньо-кваліфікаційними рівнями, встановленими державою, та органів управління освітою, що здійснюють керівництво діяльністю цих закладів. До складу цього соціального інституту, крім освітніх, можуть також входити інші заклади та установи (наукові, методичні, практичної підготовки), що забезпечують підготовку військових фахівців та сприяють ій [10].

Складовою ЄСВО є система вищої військової освіти (далі СВВ). Сьогоднішній період характеризується серйозними структурними й організаційними змінами у сфері державотворення та військового будівництва, у тому числі щодо СВВО. Характерною відмінною ознакою функціонування CBBO на сучасному етапі $є$ те, що вона виступає водночас й інструментом, й об'єктом реформування Збройних Сил України, оскільки від професійної підготовки офіцерських кадрів, їх відданості Вітчизні і спроможності виконати військовий обов'язок у найвищому ступені залежить боєготовність та боєздатність військ. На цій підставі зауважимо, що СВВО повинна забезпечити підготовку військових фахівців із високим рівнем професіоналізму, компетентності, інтелектуального розвитку, загальної та військовопрофесіональної культури, здатних 3 високою ефективністю виконувати поставлені завдання щодо оборони України, розвитку власної творчої індивідуальності, наполегливого самостійного засвоєння нових знань протягом 
військової служби, прийняття оптимальних рішень в нестандартних умовах за всіма спеціальностями й спеціалізаціями, що визначають рівень боєздатності та боєготовності Збройних Сил [5].

Водночас із позитивом розвитку військової освіти в Україні, як зазначають Щипанський П. В., Тимошенко Р. І., Салкуцан С. М. [11], що без вивчення та усунення чинників, які зумовлюють проблеми вдосконалення військової освіти, неможливе створення програмного реформування на будь-яких парадигмальних засадах. Вони визначають, що більшість із цих чинників стали очевидними у зв'язку з подіями на сході країни, іншими докорінними змінами в зовнішньому та внутрішньому безпековому середовищі держави, які сталися останніми роками та виступили каталізаторами реформ у галузі військової освіти. Вони відносіть до таких чинників та причин:

- незавершеність розроблення законодавчої бази щодо освіти в державі, зокрема нового Закону «Про освіту», затримка в імплементації окремих положень Закону України «Про вищу освіту»;

- несистемне проведення військово-професійної орієнтації молоді, національно-патріотичного виховання, початкової військової підготовки в загальноосвітніх навчальних закладах під час допризовної підготовки;

- низька ефективність реалізації політики внутрішнього та зовнішнього забезпечення якості освіти та освітньої діяльності ВВНЗ;

- недостатне впровадження в педагогічну практику основ професіографічного та компетентнісного підходів під час проектування освітньої діяльності щодо підготовки військових фахівців;

- повільне впровадження в освітній процес сучасних інформаційних, інформаційно-комунікаційних та особистісно орієнтованих педагогічних технологій;

- застарілість матеріально-технічної бази ВВНЗ, відсутність достатньої кількості сучасних зразків озброєння та військової техніки, навчальнотренувальних систем і комплексів, засобів моделювання;

- недостатнє ресурсне забезпечення та не завжди ефективне використання наявних ресурсів [11].

Система військової освіти повинна забезпечити підготовку військових фахівців із високим рівнем професіоналізму, компетентності, інтелектуального розвитку, загальної та військово-професіональної культури, здатних з високою ефективністю виконувати поставлені завдання щодо оборони України, розвитку власної творчої індивідуальності, наполегливого самостійного засвоєння нових знань протягом військової служби, прийняття оптимальних рішень в нестандартних умовах за всіма спеціальностями й спеціалізаціями, що визначають рівень боєздатності та боєготовності Збройних Сил [1].

Запровадження інтерактивних форм навчання, а сам6е ділових та рольових ігор, в освітній процес військового навчального закладу максимально наближає теоретичну підготовку до реальної практичної діяльності, тому що ділові та рольові ігри є основою прийняття рішень як в конкретній бойовій обстановці, так і на заняттях є знання законів, тенденцій розвитку військової справи, логічних методів системного аналізу. Гра - одне із чудових явищ життя, 
діяльність начебто марна i разом 3 тим необхідна. Мимоволі чаруючи й залучаючи до себе як життєве явище, гра виявилася досить серйозною й важкою проблемою для наукової думки [7; 8].

Велике значення для організації рольової гри мають прийоми, які засновані на стимулюванні ігрових взаємодій курсантів в максимальній наближеності до реальної професійної військової бойової діяльності офіцера поведінково-ігрові прийоми. До числа таких прийомів належать: інструктування, активізація ігрових сторін, корекція поведінки учасників гри, прийоми етапної та підсумкової оцінок. Особливе значення в процесі організації рольових ігор в професійні підготовці військових мають так звані когнітивно-ігрові прийоми. До таких прийомів відносяться: а) прийоми які сприяють входженню в роль - образ ( характеристика ролі кожного учасника гри, спонукання, заохочення, питання-підказка, а також підбадьорення i гумор); б) прийоми кореляції ролей (постановка навідних питань, зауваженняпитання, підтримка-захист та інше) [1; 7].

Під час дискусії, курсанти майбутні офіцера спільно опрацьовують план дій i визначають шляхи його реалізації. Вирішення ситуаційних задач спрямований не стільки на ухвалення остаточного рішення щодо проблеми, скільки на вдосконалення уміння курсантів системно аналізувати конкретну ситуацію, знаходити шляхи іiі вирішення. Головне -- виявити закономірності цієї ситуації, розкрити суттєві зв`язки системи, яка вивчається, нові факти, осмислення яких визначає уміння свідомо і цілеспрямовано впливати на систему, встановлювати шляхи ії розвитку. Ігровий метод в освітньому процесі ВВНЗ сприяє удосконаленню навичок роботи курсантів 3 різноманітною інформацією, розвитку творчого і аналітичного мислення, опануванню уміння формувати колективне рішення, створенню уявлення про методику дослідження складних військово-професійних проблем, ухваленню рішення $\mathrm{i}$ його обгрунтуванню, розвитку здібностей, висуненню перед собою реальної мети, якої можна досягти, і передбаченню наслідків рішень, які приймаються [1].

Як зазначає у доповіді генерал Салкуцан С.М.: «3 2021 року ми маємо перейти на перспективну систему військової освіти, яка передбачає серйозну кореляцією з кар'єрою офіцера, коли кожному наступному призначенню на вищу посаду передує обов'язкове підвищення рівня військової освіти [15].

32021 навчального року заочне навчання коштом державного бюджету для військовослужбовців буде припинене. При цьому враховується, що в умовах швидких змін тривалі періоди навчання офіцерів у вищих військових навчальних закладах $є$ невиправданими через стрімке старіння освітнього контенту та, крім всього іншого, фінансово обтяжливими для держави. До того ж заочна форма навчання в системі військової освіти давно зазнає критики. На зміну тривалим 2-3-річним циклам навчання офіцерських кадрів в університеті, які часто не достатньо пов'язані з офіцерською кар'єрою та не забезпечують отримання актуальних знань та умінь на конкретному етапі професійного зростання, вводиться системне оновлення професійних компетентностей відповідно до необхідного рівня військової освіти кожні 3-5 
років служби, що передбачене у проекті «Розвиток системи військової освіти та підготовки військових фахівців», який затвердив Міністр оборони України у 2018 році.

Висновки. Таким чином, в Україні створена і функціонує система підготовки військових фахівців, яка набула (змістовно) всіх ознак кращих світових зразків і дозволяє на високому рівні проводити освітню, навчальнометодичну та наукову діяльність щодо забезпечення військ (сил) висококваліфікованими кадрами. Її подальший розвиток чітко орієнтований системний підхід, основою якого $\epsilon$ захист національних інтересів i гарантування національної безпеки держави, відтворення кадрового потенціалу армії, забезпечення високої якості підготовки військових фахівців усіх освітніх рівнів 3 одночасною оптимізацією витрат на функціонування військової освітньої системи.

До подальших наукових пошуків відносимо розкриття теоретикопрактичних основ системного підходу в освітньому процесі військового навчального закладу.

\section{ЛІТЕРАТУРА}

1. Горячева К.С. Методика впровадження дидактичних та рольових ігор в освітній процес військової освіти як практика прийняття рішень в умовах обстановки наближеної до бойової // Горячева К.С., Рижиков В.С. // Молодь і ринок. - Дрогобич, 2018. - Вип. № 7 (162). - C.17 -22.

2. Конституція України // Відомості Верховної Ради України (ВВР), 1996, № 30, ст. 141.

3. Панфілов О.Ю., Петрова Л.О. Система військової освіти України як рамкова умова формування особистості військового керівника/ О.Ю. Панфілов, Л.О. Петрова// Збірник наукових праць Харківського університету Повітряних Сил, 2016, випуск 3(48). С. 201- 204.

4. Положення «Про особливості організації освітньої діяльності у вищих військових навчальних закладах Міністерства оборони України та військових навчальних підрозділах закладів вищої освіти» - Наказ Міністерства оборони України від 09 січня 2020 року № 4.

5. Полторак С. Т. Перспективні напрямки розвитку державного управління системою вищої військової освіти України / Вісник Національного університету цивільного захисту України : зб. наук. пр. - Х. : Вид-во НУЦЗУ, 2017. - Вип. 2 (7).С.309-315.

6. Про вищу освіту. Закон України від 1.07.2014 р. № 1556 - VII // Відомості Верховної Ради (ВВР), 2014, № 37-38, ст.2004.

7. Рижиков В.С. Теорія та практика використання ігрового навчання на практичних заняттях при професійній підготовці майбутніх юристів Наукові записи. Серія: педагогічні науки. - Кіровоград, 2011 вип. 99. - С.183-188.

8. Рижиков В.С. Методика використання «мозкового штурму» на семінарських заняттях в професійній підготовці у вищих військових навчальних закладах /В.С.Рижиков// Молодь і ринок - Дрогобич, Дрогобицький державний педагогічний університет імені Івана Франка. № 5 (160) травень 2018. - С.26-32

9. Рижиков В.С. Значення професійних якостей в цільовій моделі навчально-виховного процесу підготовки військових /В.С.Рижиков// Вісник Київського національного університету імені Тараса Шевченка: соціальна робота. - № 2, 2017. - С.61-64.

10. Ситник Г. Тенденції розвитку оборонно-промислового комплексу провідних країн світу / Г. Ситник, О. Сальнікова // Аспекти публічного управління. - Дніпропетровськ : Грані, 2014. - № 9/10. - С. 56-65. 
11. Щипанський П. В., Тимошенко Р. І., Салкуцан С. М. Формування нової парадигми військової освіти / П. В. Щипанський, Р. І. Тимошенко, С. М. Салкуцан // Наука і оборона 2’2017 C.37-42.

12. Bakhov I. Leadership abilities of a Military Manager, Professionalism of a Commander as the Guarantee of the Practice of Efective Activity of a Miliatry Organization / I. Bakhov, V. Ryzhykov, O. Kolisnyk. // International Journal of Engineering and Technology. - 2018. - №7. - C. 45-49.

13. Указ Президента України №240/2016 «Про рішення Ради національної безпеки і оборони України від 20 травня 2016 року «Про Стратегічний оборонний бюлетень України».

14. Урядовий портал https://www.kmu.gov.ua/news/vijskova-osvita-ye-skladovoyuzagalnoderzhavnoyi-sistemi-osviti-v-ukrayini-ta-vklyuchaye-ponad-150-specializacij-i-70specialnostej

15. Посилання: Армія Inform.

\section{REFERENCES}

1. Goryacheva K.S. Methods of introducing didactic and role-playing games in the educational process of military education as a practice of decision-making in a situation close to combat // Goryacheva KS, Ryzhikov VS // Youth and the market. - Drogobich, 2018. - Vip. № 7 (162)-P.17-22.

2. The Constitution of Ukraine // Bulletin of the Verkhovna Rada of Ukraine (VVR), 1996, № 30, Art. 141.

3. Panfilov O.Y., Petrova L.O. The system of military education of Ukraine as a framework condition for the formation of the personality of the military leader / O.Yu. Panfilov, L.O. Petrova // Collection of scientific works of Kharkiv University of the Air Force, 2016, - issue 3 (48). - Pp. 201- 204.

4. Regulation "On the peculiarities of the organization of educational activities in higher military educational institutions of the Ministry of Defense of Ukraine and military educational units of higher education institutions" - Order of the Ministry of Defense of Ukraine of January 9, 2020 № 4.

5. Poltorak ST Perspective directions of development of state management of the system of higher military education of Ukraine / Bulletin of the National University of Civil Defense of Ukraine: Collection of scientific works of Kharkiv: 2017. - Vyp. 2 (7) .- S. 309-315.

6. About higher education. Law of Ukraine of July 1, 2014 № 1556 - VII// Bulletin of the Verkhovna Rada (VVR), 2014, № 37-38, Article 2004.

7. Ryzhykov V.S. Theory and practice of using game learning in practical classes in the training of future lawyers Scientific records. Series: pedagogical sciences. - Kirovograd, 2011 issue.99-P.183-188.

8. Ryzhykov V.S. Methods of using "brainstorming" in seminars in vocational training in higher military educational institutions / VS Ryzhikov / / Youth and Market - Drohobych, Drohobych State Pedagogical University named after Ivan Franko. №5 (160) May 2018. - P.26-32.

9. Ryzhykov V.S. The value of professional qualities in the target model of the educational process of military training / V.S. Ryzhikov // Bulletin of the Taras Shevchenko National University of Kyiv: social work. - № 2, 2017. - P.61-64.

10. Sytnyk G. Tendencies of development of the defense-industrial complex of the leading countries of the world / G. Sytnyk, O. Salnikova // Aspects of public administration. Dnepropetrovsk: Grani, 2014. - № 9/10. - P. 56-65.

11. Shchipansky PV, Tymoshenko RI, Salkutsan SM Formation new paradigm of military education / PV Shchypansky, RI Tymoshenko, SM Salkutsan // Science and Defense 2'2017 P.37-42.

12. Bakhov I. Leadership abilities of a Military Manager, Professionalism of a Commander as the Guarantee of the Practice of Efective Activity of a Miliatry Organization / I. Bakhov, 
V. Ryzhykov, O. Kolisnyk. // International Journal of Engineering and Technology. - 2018. - № 7. - P. 45-49.

13. Decree of the President of Ukraine №240 / 2016 "On the decision of the National Security and Defense Council of Ukraine of May 20, 2016" On the Strategic Defense Bulletin of Ukraine ".

14. Government portal https://www.kmu.gov.ua/news/vijskova-osvita-ye-skladovoyuzagalnoderzhavnoyi-sistemi-osviti-v-ukrayini-ta-vklyuchaye-ponad-150-specializacij-i-70specialties

15. Reference: Army Inform.

\title{
PЕЗЮМЕ
}

\author{
Вадим Рыжиков, \\ доктор педагогических наук, профессор \\ Военный институт Киевского национального \\ университета имени Тараса Шевченко \\ Олег Прохоров, \\ кандидат педагогических наук, доцент \\ Военный институт Киевского национального \\ университета имени Тараса Шевченко \\ Олег Колесник, \\ кандидат психологических наук, доцент \\ Национальный университет обороны Украины \\ имени Ивана Черняховского
}

\section{Современное состояние, цели и содержание, проблемы и перспективы развития военного образования в Украине}

В статье освещаются особенности подготовки военнослужащих в современных условиях участия Украинь в гибридной войне, анализ современного состояния, иелей и содержания, проблем и перспектив развития военного образования. Военное образование базируется на принципах научности, гуманизма, демократизма, последовательности $u$ непрерывности, независимости от вмешательства каких-либо политических партий, движений, других общественных и религиозных организаџий и осуществляется на основе компетентностного подхода

В научной статье практической составляющей является внедрение интерактивных форм обучения, а именно деловых и ролевых игр в образовательном прочессе военного учебного заведения, максимально приближают теоретическую подготовку к реальной практической деятельности, так как деловые и ролевые игры являются основой принятия решений как в конкретной боевой обстановке, так и на занятиях, способствуют формированию знаний, законов, тенденций развития военного дела, логических методов системного анализа. Большое значение для организации ролевой игры имеют приемы, основанные на стимулировании игровых взаимодействий курсантов в максимальной приближенности к реальной профессиональной военной боевой деятельности офицера поведенчески-игровые приемы. К числу таких приемов относятся: инструктирование, активизаиия игровых сторон, коррекциия поведения участников игры, приемы этапной $u$ итоговой оценок. Особое значение в процессе организачии ролевых игр в профессиональной подготовке военных имеют так называемые когнитивно-игровые приемы. К таким приемам относятся: а) приемы, которые способствуют вхождению в роль - образ (характеристика роли каждого участника игры, побуждения, поощрения, вопрос-подсказка, а также ободрения и юмор) б) приемы корреляции ролей (постановка наводящих вопросов, замечания-вопросы, поддержка-защита и т.д.).

Сегоднямний период характеризуется серьезными структурными и организационными изменениями в сфере государственного и военного строительства, в том числе по системе 
выстего военного образования (СВВО). Характерным отличительным признаком функиионирования СВВО на современном этапе является то, что она выступает одновременно и инструментом, и объектом реформирования Вооруженных Сил Украины, поскольку от профессиональной подготовки офицерских кадров, их преданности Отечеству и способности выполнять воинский долг в превосходной степени зависит боеготовность и боеспособность войск. Поэтому СВВО должна обеспечить подготовку военных специалистов с высоким уровнем профессионализма, компетентности, интеллектуального развития, общей и военно-профессиональной культуры, способных $c$ высокой эффективностью выполнять поставленные задачи по обороне Украины, развития собственной творческой индивидуальности, настойчивого самостоятельного усвоения новых знаний в течение военной службы, принятие оптимальных решений в нестандартных условиях по всем специальностям и спещииализацим, определяющие уровень боеспособности и боеготовности Вооруженных Сил.

Ключевые слова: военное образование; ролевые и деловые игры; образовательный процесс военного учебного заведения; система образовательного процесса.

\section{SUMMARY}

Vadym Ryzhykov, Doctor of Science (Pedagogics), Professor Military institute of the Kiev national Taras Shevchenko university

Oleh Prokhorov,

Candidate of Pedagogical Sciences,

Associate Professor

Military institute of the Kiev national

Taras Shevchenko university

Oleh Kolisnyk,

Candidate of Psychological Sciences,

Associate Professor

National University of Ukraine named after Ivan Chernyakhovskyi

\section{Current state, objectives and content, problems and prospects of military education in Ukraine}

Introduction. The system of modern education in Ukraine is stored from the cob early training, the professional training of young people, the food education of the young people and the staff of the diploma education, including Graduates of other high school students will receive the same education and qualifications, as well as graduates of civilian students of high education - a young specialist, bachelor, master.

Purpose. Coverage of the peculiarities of military training in modern conditions of hybrid warfare, analysis of the current state, purpose and content, problems and prospects for the development of military education in Ukraine.

Methods. The article uses some general scientific and special methods of theoretical and empirical research, including analysis of the scientific literature on the problem, systematization and generalization of materials.

Results. The scientific article highlights the features of military training in the current circumstances of Ukraine's participation in the hybrid war, analysis of the current state, objectives and content, problems and prospects of military education. Military education is based on the principles of scientificity, humanism, democracy, consistency and continuity, independence from the interference of any political parties, movements, other public and religious organizations and is carried out on the basis of the competency approach. 
Originality. The system for the training of Vyskovy fakhivtsy, which was established in Ukraine, is a folding man of the state system of education. There are 12 VVNZ and VPN ZVO (2 Universities, 4 Academies, 6 Viyskovy Institutes) at the System of Viyskovo institutes; department of military training (5 - staff officers, 26 - reserve officers). Three mortgage the status "National"

Conclusion. The practical component is the introduction of interactive forms of education namely business and role-playing games in the educational process of military educational institution, which bring theoretical training as close as possible to real practice, because business and role-playing games are the basis of decision-making both in specific combat situations and in classes, they contribute to the formation of knowledge, laws, trends in military affairs, logical methods of system analysis. Role-playing techniques such as behavioral-game techniques are very important, they are based on stimulating the game interactions of cadets in close proximity to the real professional military combat activities of an officer. Such techniques include: instruction, activation of game parties, correction of the game participants behavior, step and final evaluation techniques. The so-called cognitive-game techniques are of particular importance in the organization of role-playing games in the military training. Such techniques include: a) techniques that promote entry into the role - image (description of each participant role in the game, motivation, encouragement, question-hint, as well as encouragement and humor); b) methods of role correlation (leading questions, comments - questions, support - defence etc.).

Key words: military education; role and business games; the educational process of military educational institution; the educational process system. 